\title{
MiR-582-3p Participates in the Regulation of Biological Behaviors of A549 Cells by Ambient PM2.5 Exposure
}

\section{Liangliang Ju}

Anhui Medical University School of Public Health

\section{Mei Yang}

Anhui Medical University School of Public Health

Changlian Li

Anhui Medical University School of Public Health

\section{Han Cheng}

Anhui Medical University

$\mathrm{Na} \mathrm{Li}$

Department of Oncology,thy Second Affiliated Hospital of Anhui Medical University

\section{Qi Zhang}

Anhui Medical University School of Public Health

\section{Shu Sun}

Anhui Medical University School of Public Health

Liu Ding

Anhui Medical University School of Public Health

Xinmiao Sui

Anhui Medical University School of Public Health

Chao Zhang

Anhui Medical University School of Public Health

\section{Mingwei Yang}

First Affiliated Hospital of Anhui Medical University

Jiyu Cao

Anhui Medical University School of Public Health

Rui Ding ( $\square$ kilthy@ahmu.edu.cn )

Anhui Medical University School of Public Health

\section{Research}

Keywords: Atmospheric PM2.5, lung cancer, miR-582-3p, EMT, Wnt/ $\beta$-catenin signaling pathway 
Posted Date: June 9th, 2021

DOl: https://doi.org/10.21203/rs.3.rs-571917/v1

License: (c) (i) This work is licensed under a Creative Commons Attribution 4.0 International License. Read Full License 


\section{Abstract}

\section{Background}

Ambient fine particulate matter $\left(\mathrm{PM}_{2.5}\right)$ is one of the main environmental air pollutants that closely related to the development of lung cancer, but the mechanisms are unclear.

Results

In this study, A549 cells were exposed to ambient $\mathrm{PM}_{2.5}$ to investigate the alterations of biological behaviors, and the possible role of miR-582-3p in the effects was further explored. The findings showed that that $\mathrm{PM}_{2.5}$ exposure could significantly enhance the biological behaviors of A549 cells, and promote their EMT transformation, especially at relatively low doses. Over-activation of $\mathrm{Wnt} / \beta$-catenin signaling pathway and increased expression of miR-582-3p were also found in A549 cells after $\mathrm{PM}_{2.5}$ exposure. After the knockdown of miR-582-3p in A549 cells, the effects of $\mathrm{PM}_{2.5}$ on malignant biological behavior changes, EMT and the activation of Wnt/ $\beta$-catenin signaling pathway were all significantly alleviated. Furthermore, the inhibition of Wnt/ $\beta$-catenin signaling pathway also inhibited the EMT process of A549 cells, which was rescued by the overexpression of miR-582-3p.

\section{Conclusion}

This study showed that ambient $\mathrm{PM}_{2.5}$ can up-regulate the expression of miR-582-3p, consequently activate the Wnt/ $\beta$-catenin signaling pathway, thereby enhance EMT transformation and promote the malignant biological behaviors of A549 cells. These findings provide evidence for further research into the mechanisms by which exposure to $\mathrm{PM}_{2.5}$ in the environment promotes lung cancer.

\section{Introduction}

Air pollution is a major environmental issue that has substantial impacts on human health throughout the world[1]. Fine particulate matters $\left(\mathrm{PM}_{2.5}\right)$, the particulate matters with the aerodynamic diameter of $\leq$ $2.5 \mu \mathrm{m}$, is one of the primary ambient pollutants. Due to the small particle size, light weight and high dispersion, $\mathrm{PM}_{2.5}$ can suspend in the air for long time and enter the alveoli through the respiratory tract. Part of the particulate matters can also pass through the alveolar epithelium and enter the blood circulation through the lung tissue gap[2]. In addition, the small particle size and specific surface area allow $\mathrm{PM}_{2.5}$ to adsorb a variety of toxic and harmful substances, thus increasing the complexity of effects. The International Agency for Research on Cancer (IARC) has classified particulate matter in ambient air as a Class I carcinogen[3].

Lung cancer is still one of the most life-threatening malignancies with high morbidity and mortality. Previous studies have shown that a quarter of cancer deaths in the world are caused by lung cancer[4], and lung cancer metastasis is the main cause of death in lung cancer patients[5]. Lung cancer is the second most common diagnosed cancer and the leading cause of cancer death, accounting for 
approximately one tenth (11.4\%) of all diagnosed cancers and one fifth $(18.0 \%)$ of all deaths worldwide in 2020 with approximately 2.2 million new cases and 1.8 million deaths[6]. To date, a large number of epidemiological studies have shown that $\mathrm{PM}_{2.5}$ is closely related to the occurrence and development of lung cancer and the increased risk of lung cancer death[7-9], while the underlying biological mechanisms are still unclear. Accumulating evidence has shown that non-coding RNAs play critical roles in the occurrence and progression of lung cancer[10].

MicroRNAs (miRNAs) are a class of endogenous, non-coding single-stranded small RNAs with the length of about 20-24 nucleotides that widely exist in eukaryotes. It is well known that miRNAs play important roles in regulating protein translation and transcription. Specifically, miRNA mainly inhibits or blocks the translation of a variety of target proteins through complementary binding with the 3 '-untranslated region of target messenger RNA, therefore regulates cell proliferation, differentiation, apoptosis, and metabolism[11]. A large number of studies have shown that many miRNAs act as oncogenes or tumor suppressors, and play vital roles in cancer development and progression. Specifically, miRNAs can regulate the biological processes of a variety of cells, including cell proliferation, differentiation, invasion, migration, etc., thereby regulating the development of a variety of tumors[12, 13]. Recent studies have shown that miR-582-3p is overexpressed in lung cancer cell lines and tissues and has carcinogenic and cancer-promoting effects. Moreover, miR-582-3p is closely related to the pathway of cancer, and its target genes are abundantly enriched in the Wnt signaling pathway $[14,15]$. Wnt/ $\beta$-catenin signaling pathway is a classic cell signal transduction pathway, which is involved in mediating cell growth, migration, differentiation and apoptosis, and is a key signaling pathway for tumorigenesis and prognosis. Based on these, this study explored the role of miR-582-3p in biological behavior changes of human lung adenocarcinoma cells (A549) after $\mathrm{PM}_{2.5}$ exposure.

\section{Results}

\section{Cytotoxic effects}

The effect of different concentrations of $\mathrm{PM}_{2.5}(0,25,50,100,200 \mu \mathrm{g} / \mathrm{mL})$ on the viability of A549 cells was detected by MTT assay. The A549 cytotoxic effect of $\mathrm{PM}_{2.5}$ was shown in Fig. $1 \mathrm{~A}$. After 24 hours exposure, the survival rate of cells decreased with the increase of $\mathrm{PM}_{2.5}$ concentration in a dose-response relationship. When $\mathrm{PM}_{2.5}$ exposure reached $100 \mu \mathrm{g} / \mathrm{mL}$ or higher, the cell survival rate was significantly lower than that of the control group $(P<0.01)$, and the cell survival rate was about $80 \%$ when $\mathrm{PM}_{2.5}$ concentration was $100 \mu \mathrm{g} / \mathrm{mL}$. For the purpose of investigating the role of $W n t / \beta$-catenin, the specific inhibitor DKK-1 was also used in this study. MTT assay showed that the effects of different concentrations of DKK-1 $(0,25,50,100,200 \mathrm{ng} / \mathrm{mL})$ on the viability of A549 cells. After 24 hours exposure, the cell viability of DKK-1 decreased gradually with the increase of DKK-1 concentration. When the concentration of DKK-1 was $50 \mathrm{ng} / \mathrm{mL}$, there was no difference in the effect of DKK-1 on cell viability compared with that of the single solvent group $(\mathrm{P}>0.05)$ (Fig. 2B). Therefore, $\mathrm{PM}_{2.5}$ doses of 0 (pure 
solvent control, containing 1\%o DMSO), $25,50,100 \mu \mathrm{g} / \mathrm{mL}$, and DKK-1 dose of $50 \mathrm{ng} / \mathrm{mL}$ were selected for the treatment in this study.

\section{$\mathrm{PM}_{2.5}$ promoted the proliferation, migration and invasion of A549 cells}

According to the MTT assay, A549 cells were treatment with different concentrations of $\operatorname{PM}_{2.5}(0,25,50$, $100 \mu \mathrm{g} / \mathrm{mL}$ ) for 24 hours, and then the cell proliferation ability was detected by plate clonal formation assay. As shown in Fig. 2A and 2B, the number of cloned cells increased significantly in the $25 \mu \mathrm{g} / \mathrm{mL}$ $\mathrm{PM}_{2.5}$ treatment group $(P<0.01)$, comparing with the control group $(0 \mu \mathrm{g} / \mathrm{mL})$. Interestingly, the number of cell clones in the $50 \mu \mathrm{g} / \mathrm{mL}$ and $100 \mu \mathrm{g} / \mathrm{mL}$ groups also increased, but not as substantial as in the 25 $\mu \mathrm{g} / \mathrm{mL}$ group.

To assess the migration of cells, A549 cells were exposed to $\mathrm{PM}_{2.5}(0,25,50,100 \mu \mathrm{g} / \mathrm{mL})$ for 12 , 24, and 36 hours, the migration distance of the cells in the scratched area was measured. As shown in Fig. $2 \mathrm{C}$, the cell migration distances were significantly different among different groups 24 hours later. The wound closure rate in the 25 and $50 \mu \mathrm{g} / \mathrm{mL}$ group was $65.4 \% \pm 3.8 \%$ and $42.8 \% \pm 2.9 \%$, respectively, which were significantly higher than in the control group $(30.3 \% \pm 3.1 \%)(P<0.05)$ (Fig. $2 \mathrm{D})$.

To assess the invasion capability of cells, $A 549$ cells were exposed to $\mathrm{PM}_{2.5}(0,25,50,100 \mu \mathrm{g} / \mathrm{mL})$ for 24 hours, the invasion capability of the cells was detected by transwell assay. The results showed that the number of invaded cells in the 25 and $50 \mu \mathrm{g} / \mathrm{mL}$ groups increased significantly compared with the control group $\left(0 \mu \mathrm{g} / \mathrm{mL}\right.$ group) $(P<0.05)$. However, the further increase of $\mathrm{PM}_{2.5}$ concentration resulted in lower cell invasion (Fig. 2E and 2F).

\section{$\mathrm{PM}_{2.5}$ induced EMT in A549 cells}

The biological behaviors of cells after $\mathrm{PM}_{2.5}$ treatment showed that $\mathrm{PM}_{2.5}$ with the concentration of 25 $\mu \mathrm{g} / \mathrm{mL}$ had the strongest effects. Therefore, A549 cells were exposed to $\mathrm{PM}_{2.5}$ at concentrations of 0 , $6.25,12.5$, and $25 \mu \mathrm{g} / \mathrm{mL}$ for 24 hours, and the expression of EMT-related proteins were measured by western blot (Fig. 3A). Quantitative analysis showed that with the increase of $\mathrm{PM}_{2.5}$ concentrations, the expression of Vimentin tended to increase in dose-dependent manner. Specifically, after the cells were exposed to $\mathrm{PM}_{2.5}$ at $6.25 \mu \mathrm{g} / \mathrm{mL}$ or higher, the protein expression level of vimentin was significantly higher than that of control group. Similarly, with the increase of $\mathrm{PM}_{2.5}$ concentration, the protein expression level of E-cadherin showed a dose-dependent decrease trend, which were significantly lower than control group $(P<0.05)$ (Fig. 3B).

\section{$\mathrm{PM}_{2.5}$ activated Wnt/ $\beta$-catenin signaling pathway in A549 cells}

After treated with different concentrations of $\mathrm{PM}_{2.5}(0,25,50,100 \mu \mathrm{g} / \mathrm{mL})$ for 24 hours, the levels of Wnt/

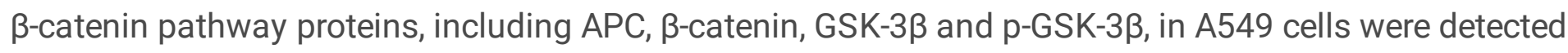


by Western blot. The results were shown in the Fig. 4A. Compared with the control group, the expression level of $\beta$-catenin and the relative expression level of P-GSK-3 $\beta$ /GSK-3 $\beta$ in A549 cells in the PM 2.5 treatment group were significantly increased $(P<0.05)$, while the expression level of APC was significantly decreased $(P<0.01)$, in a dose-response relationship (Fig. 4B).

\section{$\mathrm{PM}_{2.5}$ altered miR-582-3p expression in A549 cells}

After treated with different concentrations of $\mathrm{PM}_{2.5}(0,25,50,100 \mu \mathrm{g} / \mathrm{mL})$ for 24 hours, the QRT-PCR results showed that compared with the control group, the expression levels of miR-582-3p in the $\mathrm{PM}_{2.5}$ exposure groups were significantly increased $(P<0.01)$. The expression levels of miR-582-3p of $50 \mu \mathrm{g} / \mathrm{mL}$ and $100 \mu \mathrm{g} / \mathrm{mL} \mathrm{PM}_{2.5}$ exposure groups were the highest, and there was no significant difference between the two groups. (Fig. 5).

\section{MiR-582-3p mediated $\mathrm{PM}_{2.5}$-induced proliferation, migration and invasion of A549 cell}

In order to further explore the mechanism of miR-582-3p in the biobehavioral changes of A549 cells caused by $\mathrm{PM}_{2.5}$, miR-582-3p mimics NC, miR-582-3p mimics, miR-582-3p inhibitor NC and miR-582-3p inhibitor were transfected into A549 cells, and the expression level of miR-582-3p was detected by QRTPCR assay. Comparing with the miR-582-3p mimics NC group and miR-582-3p inhibitor NC group, the miR-582-3p expression was significantly up-regulated in the miR-582-3p mimics group, and significantly down-regulated in the miR-582 -3p inhibitor group $(P<0.01$; Fig. 6$)$. These findings proved that the transfection was successful.

MiR-582-3p inhibitor was transfected into A549 cells to knock down the expression of miR-582-3p, and then the cells were exposed to $\mathrm{PM}_{2.5}(50 \mu \mathrm{g} / \mathrm{mL})$ for 24 hours. The plate clone formation assay showed that comparing with the miR-582-3p inhibitor NC group, the clonal formation ability of A549 cells in the miR-582-3p inhibitor group was significantly decreased $(P<0.05)$ (Fig. 7A), and the clonal formation ability of $A 549$ cells in the miR-582-3p inhibitor $+\mathrm{PM}_{2.5}$ group was significantly improved compared with the miR-582-3p inhibitor group $(P<0.01)$ (Fig. 7B).

The ability of migration was evaluated by wound healing assay. The results showed that after 24 hours of exposure, the wound healing rate was significantly different among the groups. Specifically, the miR582-3p inhibition significantly reduced the wound healing rate of A549 cells, comparing with the miR-582$3 p$ inhibitor NC group $(26.2 \% \pm 1.2 \%$ vs. $43.8 \% \pm 2.4 \%)(P<0.05)$, while treatment with $\mathrm{PM}_{2.5}$ significantly rescued the wound healing capability of cells with miR-582-3p inhibition $(63.4 \pm 2.3 \%$ vs. $26.2 \% \pm 1.2 \%)(P$ $<0.01$ ) (Fig. 7C and 7D).

The invasion capability of the cells was evaluated by transwell invasion assay. The result was shown in Fig. 7E and 7F. After 24 hours of exposure, compared with the miR-582-3p inhibitor NC group, the number of invaded cells in the miR-582-3p inhibitor group was significantly reduced $(P<0.05)$, the number of 
invaded cells in miR-582-3p inhibitor $+\mathrm{PM}_{2.5}$ group was significantly increased compared with miR-582$3 p$ inhibitor group $(P<0.05)$.

\section{MiR-582-3p mediated PM 2.5 -induced EMT in A549 cells}

The role of miR-582-3p in EMT of A549 cells was further investigated. After treated with $\mathrm{PM}_{2.5}(50$ $\mu \mathrm{g} / \mathrm{mL}$ ) for 24 hours, the expression of EMT-related proteins, such as Vimentin and E-cadherin, were detected by Western blot. The results showed that comparing with the miR-582-3p inhibitor NC group, the expression of Vimentin in the miR-582-3p inhibitor group was significantly decreased, while the expression of E-cadherin was significantly increased $(P<0.05)$. In addition, comparing with the miR-582$3 p$ inhibitor group, the expression of Vimentin in the miR-582-3p inhibitor $+\mathrm{PM}_{2.5}$ group significantly increased, while the expression of E-cadherin was decreased significantly $(P<0.05)$ (Fig. 8).

\section{MiR-582-3p mediated the activation of Wnt/ $\beta$-catenin signaling pathway in A549 cells induced by $\mathrm{PM}_{2.5}$}

Role of miR-582-3p in the activation of Wnt/ $\beta$-catenin signaling pathway in A549 cells was further investigated. After transfection, the $A 549$ cells were treated with $\mathrm{PM}_{2.5}(50 \mu \mathrm{g} / \mathrm{mL})$ for 24 hours, and then

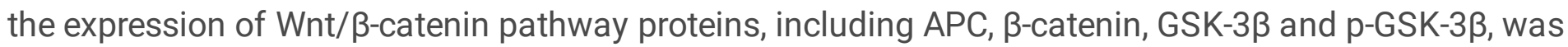
detected by Western blot. Comparing with the miR-582-3p inhibitor NC group, the expression of $\beta$-catenin and the relative expression of $p-G S K-3 \beta / G S K-3 \beta$ in the miR-582-3p inhibitor group were significantly decreased, while that of APC was significantly increased $(P<0.05)$ (Fig. 9). In addition, compared with the miR-582-3p inhibitor group, the expression of $\beta$-catenin and the relative expression of $p-G S K-3 \beta / G S K-3 \beta$ in the miR-582-3p inhibitor $+\mathrm{PM}_{2.5}$ group were significantly increased, while the expression of APC significantly decreased $(P<0.05)$ (Fig. 9).

\section{MiR-582-3p regulates the EMT process of A549 cells through the Wnt/ $\beta$-catenin signaling pathway}

DKK-1, a Wnt/ $\beta$-catenin inhibitor was used in this study to explore the mechanism underlying the regulatory effects of miR-582-3p on EMT of A549 cells. Cells were transfected with miR-582-3p mimics to induce the overexpression of miR-582-3p (Fig. 6), and then DKK-1 was used to inhibit the Wnt/ $\beta$-catenin pathway. As shown in Fig. 10, comparing with the miR-582-3p mimics NC group, the protein expression of Vimentin in the miR-582-3p mimics group was significantly up-regulated, while the protein expression of E-cadherin was significantly down-regulated $(P<0.05)$. Compared with miR-582-3p mimics group, the protein expression of Vimentin in miR-582-3p mimics + DKK-1 group was significantly down-regulated, while the expression level of E-cadherin was significantly up-regulated $(P<0.05)$.

\section{Discussion}

The results of this study showed that exposure to ambient $\mathrm{PM}_{2.5}$ significantly enhanced the abilities of proliferation, migration and invasion of A549 cells. In addition, the EMT marker protein Vimentin of A549 
cells was significantly up-regulated, and E-cadherin was significantly down-regulated. The Wnt/ $\beta$-catenin signaling pathway in the cell was highly activated after $\mathrm{PM}_{2.5}$ exposure, and the expression level of $\beta$ catenin and the relative expression level of $p-G S K-3 \beta / G S K-3 \beta$ increased significantly, while the expression level of APC decreased significantly. In addition, the study also found that the effect of $\mathrm{PM}_{2.5}$ exposure on the biological behavior changes of A549 cells was most significant at a concentration of $25 \mu \mathrm{g} / \mathrm{mL}$ $\mathrm{PM}_{2.5}$. However, when the concentration of $\mathrm{PM}_{2.5}$ continued to increase, the promoting effects of $\mathrm{PM}_{2.5}$ on the proliferation, migration, invasion and EMT of A549 cells all decreased and even disappeared. It may be due to the toxic effect of high concentrations of $\mathrm{PM}_{2.5}$ on A549 cells. Similarly, the study by Zhou W et al [16] also pointed out that repeated exposure to "safe" concentrations of $\mathrm{PM}_{2.5}$ induces epigenetic silence of P53, which is an approved tumor suppressor gene, but the epigenetic effect caused by shortterm exposure to high-dose $\mathrm{PM}_{2.5}$ was completely difference.

Further studies showed that the expression level of miR-582-3p in A549 cells was increased after $\mathrm{PM}_{2.5}$ exposure, and knockdown of miR-582-3p expression significantly inhibited cell proliferation, migration and invasion in A549 cells. In addition, the activation of Wnt/ $\beta$-catenin signaling pathway and EMT were also inhibited. But the addition of $\mathrm{PM}_{2.5}$ can obviously rescue these effects. In order to explore the regulatory effect of $\mathrm{Wnt} / \beta$-catenin signaling pathway on EMT, further experiments were carried out by using DKK-1 to inhibit the Wnt/ $\beta$-catenin pathway, and then detecting the effect of miR-582-3p overexpression on EMT. The results showed that after overexpression of miR-582-3p in A549 cells, intracellular EMT was significantly increased, but the EMT of the DKK-1 intervention group was significantly down-regulated compared with the non-intervention group. The important role of Wnt/ $\beta$ catenin signaling pathway in promoting EMT in cancer cells has been confirmed by many studies[17, 18], and the results of this study also add new evidence for this. The reduction of E-cadherin during EMT is largely regulated by $\mathrm{Wnt} / \beta$-catenin signaling. The E-cadherin/ $\beta$-catenin complex plays an important role in maintaining the stable connection of epithelial cells. Once the E-cadherin/ $\beta$-catenin complex is disturbed or destroyed, it will eventually lead to the nuclear translocation of $\beta$-catenin and the transcriptional activation of EMT-promoting genes. The regulatory role of Wnt / $\beta$-catenin-EMT in the development of lung cancer has also been gradually confirmed $[19,20]$. Therefore, the above results indicated that $\mathrm{PM}_{2.5}$ exposure leaded to the overexpression of miR-582-3p in A549 cells, which activated the Wnt/ $\beta$-catenin signaling pathway and further enhanced EMT, ultimately caused malignant biological behavior changes.

Previous studies have shown that miR-582-3p promotes stem cell characterization of NSCLC cells in vitro and is inversely associated with overall and relapse-free survival in patients[14, 21]. Studies have reported that miR-582-3p can specifically inhibit Axin2, DKK3 and SFRP1- common tumor suppressors in human malignancies including NSCLC, thereby over-activating Wnt/ $\beta$-catenin signal transduction and playing an important role in the progression of lung cancer[14]. Jin $X$ et $a / 15]$ also confirmed that miR-582-3p is closely related to the pathway of cancer through pathway enrichment analysis, and its target genes are abundantly enriched in the Wnt signaling pathway. All these studies provide a theoretical basis for our research results. However, some studies have found that the increased expression of miR-582-3p can 
reduce the proliferation and invasion of some cancers, such as prostate cancer[22] and gastric cancer[23]. Based on these findings, miR-582-3p seems to have both anti-tumor and pro-tumor effects.

In conclusion, this study confirmed that $\mathrm{PM}_{2.5}$ has a strong effect on causing lung cancer, and also confirmed the regulatory role of miR-582-3p and Wnt/ $\beta$-catenin signaling pathway in this process. However, the specific target of Wnt/ $\beta$-catenin signaling pathway that miR-582-3p acting on needs to be further explored. In addition, our current study is only established at the cell level in vitro, and verification in vivo experiments are needed in the future.

\section{Conclusion}

This study demonstrated that ambient $\mathrm{PM}_{2.5}$ could up-regulate the expression of miR-582-3p, consequently activates the Wnt/ $\beta$-catenin signaling pathway, and enhances EMT transformation and promotes malignant biological behaviors of A549 cells. These findings provided evidence for further investigating the mechanisms underlying the lung cancer-promoting effects of ambient $\mathrm{PM}_{2.5}$ exposure.

\section{Materials And Methods}

\section{Collection and extraction of ambient $\mathrm{PM}_{2.5}$}

$\mathrm{PM}_{2.5}$ samples were collected in Shushan District, Hefei City, which is the capital city of Anhui province and one of the most polluted cities in China. In detail, the ultrafine glass fiber filter membrane with the pore size of $0.2 \mu \mathrm{m}$ was installed on the $\mathrm{PM}_{2.5}$ sampler for $\mathrm{PM}_{2.5}$ collection, with the flow rate of 1 $\mathrm{m}^{3} / \mathrm{min}$, and the sampling time from 9:00 am to 16:00 pm. The dried filter membrane was cut into 1 $\mathrm{cm} \times 1 \mathrm{~cm}$, put into a beaker containing deionized water, and sonicated for 3 times by an ultrasonic oscillator, with 10 min in each sonication. After filtration, the dry $\mathrm{PM}_{2.5}$ was dispersed in water for more than 24 hours at low temperature, and then dissolved in DMSO to obtain the $\mathrm{PM}_{2.5}$ stock solution, of which the concentration was $100 \mathrm{mg} / \mathrm{ml}$, and store at $-20^{\circ} \mathrm{C}$ in dark.

\section{Cell culture and transfection}

A549 cells (Procell Life Science\&Technology Co,.Ltd.) were kindly provided by the University of Science and Technology of China. A549 were cultured with DMEM medium containing $10 \%$ fetal bovine serum and $1 \%$ penicillin streptomycin solution in a constant temperature incubator at $5 \% \mathrm{CO}_{2}$ and $37{ }^{\circ} \mathrm{C}$. For cell transfection, A549 cells were seeded in 6-well plates and cultured in DMEM containing 10\% fetal bovine serum but no antibiotics until cell density reached $60-70 \%$, afterwards the lipofectamine 2000 kit (Invitrogen; Thermo Fisher Scientific, Inc.) was used for the transfection of the cells, according to the instructions of manufacturers. RNA was extracted 24 hours after transfection for further analysis. Cell behaviors were assessed $48-72$ hours later. All experiments were independently repeated for 3 times. The transfections were designed and synthesized by Gemma Technology (China) Co., Ltd, and the sequences are shown in Table $\mathrm{S} 1$. 


\section{Cell viability test}

3-(4, 5-dimethyl-2-thiazolyl)-2, 5-diphenyl-2-H-tetrazolium bromide (MTT) assay was used to assessed the toxic effects of $\mathrm{PM}_{2.5}$ and DKK-1 on A549 cells. The cell suspension at a concentration of $5 \times 10^{4}$ cells $/ \mathrm{mL}$ was seeded into the 96 -well plate at $100 \mu \mathrm{L}$ per hole, and cultured until density reached $70-80 \%$.

Then medium containing pre-defined concentrations of $\mathrm{PM}_{2.5}(0,25,50,100$ and $200 \mu \mathrm{g} / \mathrm{mL})$ or DKK-1 (0, $25,50,100$ and $200 \mathrm{ng} / \mathrm{mL}$ ), as well as blank control (with only culture medium) were placed in the incubator respectively, and the cells were further cultured for 24 hours. Afterwards, $200 \mu \mathrm{L}$ of MTT solution was added into each well for further incubation of 4 hours, and $150 \mu \mathrm{L}$ DMSO was added to each well, and the 96-well plate was oscillated on a horizontal shaker until the precipitate is completely dissolved. The absorbance value of each well was measured by ELx800 microplate reader at $490 \mathrm{~nm}$.

\section{Plate clone formation assay}

The cell concentration was adjusted to $2 \times 10^{3}$ cells $/ \mathrm{mL}$ with the DMEM medium, then $300 \mu \mathrm{L}$ cell suspension was added to 6 -well cell-culture dish (diameter of each well was $3.48 \mathrm{~cm}$ ), and culture medium was added until the volume was $3 \mathrm{~mL}$. The cells were cultured in the incubator, until the clones were visible. After washing with PBS for 3 times, the clones were fixed with $4 \%$ paraformaldehyde for 25 minutes, stained with $0.1 \%$ crystal violet solution for 15-20 minutes, and then washed and dried. The number of clones was counted under light microscope, and calculated according to the formula: clone formation rate $=$ (number of cloned cells) $/$ (number of inoculated cells) $\times 100 \%$.

\section{Wound healing assay}

After A549 cells were cultured in a 6-well plate to form monolayer, which was scratch by the tip of a 200 $\mu \mathrm{L}$ sterilized pipette perpendicularly to create the wound, and then washed with PBS for 3 times to remove the exfoliated cells. The culture medium of different treatment groups was added to each hole and placed in the incubator for further culture. The migrations of cells at the scratch sites were photographed with an inverted microscope every 12 hours. The Image J software (Tanon Gel Image System 4.2) was used to measure the migration distance of cells and the wound healing rate was calculated according to the migration distance.

\section{Transwell cell invasion assay}

Transwell cell invasion assay was used to assess the ability of cells invasion. The Matrigel was diluted and mixed with pre-chilled serum-free cell culture medium on ice at a ratio of $1: 7$, and then $50 \mu \mathrm{L}$ of diluted matrigel was applied evenly in the upper chamber of transwell culture plate. After solidification of the matrigel, $200 \mu \mathrm{L}$ of the cell suspension prepared in serum-free medium was added to the upper chamber. While in the lower chamber, $600 \mu \mathrm{L}$ complete medium containing $20 \% \mathrm{FBS}$ and different concentrations of $\mathrm{PM}_{2.5}(0,25,50,100 \mu \mathrm{g} / \mathrm{mL})$ was added, respectively. The cells were cultured in a 37 ${ }^{\circ} \mathrm{C}$ constant temperature incubator containing $5 \% \mathrm{CO}_{2}$ for 24 hours. Then the matrigel was removed, and the cells were fixed with $4 \%$ paraformaldehyde for 25 minutes. Afterwards, the chamber membrane was stained with $0.1 \%$ crystal violet for 20 minutes, rinsed with deionized water for 3 times, and the cell 
numbers in 3 random sights were counted under the inverted microscope. The average number was calculated for the comparison.

\section{Western blot}

Western blot was used to detect the expression of epithelial-mesenchymal transition (EMT) and Wnt/ $\beta$ catenin signaling pathway proteins in cells. The cells were lysed and centrifuged, and the supernatant, namely the total cellular protein, was pipetted into a new centrifuge tube, which was quantified with the BCA protein quantitative kit (P0010, Beyotime Biotechnology). Proteins of different molecular weights were separated by electrophoresis, and then transferred to PVDF membranes by SDS-PAGE. The PVDF membranes were blocked in a 5\% skim milk blocking solution at room temperature for 2 hours, and incubated with a specific primary antibody at $4^{\circ} \mathrm{C}$ overnight. After rinsing, the membrane was incubated with pre-diluted secondary antibody for 2 hours at room temperature and then developed. The gray scale of the band was analyzed with Image $\mathrm{J}$ gray analysis software (Tanon Gel Image System 4.2).

\section{QRT-PCR}

Primers were designed according to the sequences of the genes to detect the corresponding mRNA expression level of the cells. The sequences of the primers are shown in Table S2. RNA was extracted from the cells according to the instructions of the RNA extraction kit, and the RNA concentration in each

group was determined by an ultraviolet-visible spectrophotometer (Nanodrop one). RNA was transcribed into CDNA in a reverse PCR instrument $\left(T 100^{\mathrm{TM}}\right.$ Thermal Cycler) using the PrimeScript ${ }^{\mathrm{TM}}$ RT reagent kit with gDNA Eraser (RR047A, TaKaRa), and cDNA was amplified on a Light Cycler 96 real-time PCR instrument (LightCycler® 96 Instrument) using the TB Green ${ }^{\circledR}$ Premix Ex Taq ${ }^{\text {TM }}$ II reagent kit (RR820A, TaKaRa). The relative expression of the target gene was calculated using the $2^{-\Delta \Delta C t}$ formula method.

\section{Statistical analysis}

SPSS 23.0 was used for statistical analysis. All the data in the experiment were expressed as mean \pm standard deviation ( $x \unrhd \pm S D$ ), the quantitative data between the two groups and multiple groups were analyzed by independent-samples t-test and One-way ANOVA of variances. $P<0.05$ indicated statistically significant.

\section{Abbreviations}

$\mathrm{PM}_{2.5}$ : Fine particulate matter

IARC: International Agency for Research on Cancer

MiRNAs: MicroRNAs

MTT: 3-(4, 5-dimethyl-2-thiazolyl)-2, 5-diphenyl-2-H-tetrazolium bromide

DMSO: Dimethyl sulfoxide 
EMT: Epithelial-mesenchymal transition

QRT-PCR: Quantitative Real-time Polymerase Chain Reaction

DMEM: Dulbecco's modified Eagle's medium

PBS: phosphate buffer saline

FBS: Fetal bovine serum

PVDF: Polyvinylidene Fluoride

SDS-PAGE: dodecyl sulfate, sodium salt (SDS)-Polyacrylamide gel electrophoresis

\section{Declarations}

\section{Ethics declarations}

\section{- Ethics approval and consent to participate}

not applicable.

\section{- Consent for publication}

All authors have read and approved the manuscript. The need for publication is not applicable.

\section{- Competing interests}

The authors declare that they have no competing interest

\section{Availability of data and materials}

All data analyzed within this study are included either in the manuscript or in the additional supplementary files.

\section{Funding}

This work was supported by the Project Foundation for the Young Talents in Colleges of Anhui Province (No. gxyq2017003), the Grant for Scientific Research of BSKY from Anhui Medical University (No. XJ201621), the National Natural Science Foundation of China (No. 81872580), and the Student's Platform for Innovation and Entrepreneurship Training Program of China (No. 201810366031). 


\section{Author's contributions}

MY and CLL performed the experiments. LLJ, MY and RD prepared the manuscript. QZ, SS and LD analyzed the data and made the graphs. $\mathrm{HC}, \mathrm{CZ}, \mathrm{NL}$ and XMS conducted the statistical analysis. LLJ, MY and $\mathrm{RD}$ reviewed and edited the manuscript. RD, JYC and MWY supervised this research project. The manuscript was written through the contributions of all authors. All authors have approved the final version of the manuscript.

\section{Acknowledgements}

Not applicable.

\section{Additional information}

\section{Publisher's Note}

Springer Nature remains neutral with regard to jurisdictional claims in published maps and institutional affiliations.

\section{References}

1. Chen EK, Zmirou-Navier D, Padilla C, Deguen S: Effects of air pollution on the risk of congenital anomalies: a systematic review and meta-analysis. Int J Environ Res Public Health 2014, 11(8):76427668.

2. Yue $S$, Wang $Y$, Wang J, Chen J: Relationships between lung cancer incidences and air pollutants. Technol Health Care 2017, 25(S1):411-422.

3. Loomis D, Grosse Y, Lauby-Secretan B, El Ghissassi F, Bouvard V, Benbrahim-Tallaa L, Guha N, Baan $\mathrm{R}$, Mattock H, Straif $\mathrm{K}$ et al: The carcinogenicity of outdoor air pollution. Lancet Oncol 2013, 14(13):1262-1263.

4. Siegel RL, Miller KD, Jemal A: Cancer statistics, 2019. CA Cancer J Clin 2019, 69(1):7-34.

5. Okimoto RA, Breitenbuecher F, Olivas VR, Wu W, Gini B, Hofree M, Asthana S, Hrustanovic G, Flanagan J, Tulpule A et al: Inactivation of Capicua drives cancer metastasis. Nat Genet 2017, 49(1):87-96.

6. Sung H, Ferlay J, Siegel RL, Laversanne M, Soerjomataram I, Jemal A, Bray F: Global cancer statistics 2020: GLOBOCAN estimates of incidence and mortality worldwide for 36 cancers in 185 countries. CA Cancer J Clin 2021.

7. Raaschou-Nielsen O, Andersen ZJ, Beelen R, Samoli E, Stafoggia M, Weinmayr G, Hoffmann B, Fischer $\mathrm{P}$, Nieuwenhuijsen MJ, Brunekreef $\mathrm{B}$ et al: Air pollution and lung cancer incidence in 17 
European cohorts: prospective analyses from the European Study of Cohorts for Air Pollution Effects (ESCAPE). Lancet Oncol 2013, 14(9):813-822.

8. Pun VC, Kazemiparkouhi F, Manjourides J, Suh HH: Long-Term PM2.5 Exposure and Respiratory, Cancer, and Cardiovascular Mortality in Older US Adults. Am J Epidemiol 2017, 186(8):961-969.

9. Tseng CH, Tsuang BJ, Chiang CJ, Ku KC, Tseng JS, Yang TY, Hsu KH, Chen KC, Yu SL, Lee WC et al: The Relationship Between Air Pollution and Lung Cancer in Nonsmokers in Taiwan. J Thorac Oncol 2019, 14(5):784-792.

10. Wang M, Ma X, Zhu C, Guo L, Li Q, Liu M, Zhang J: The prognostic value of long non coding RNAs in non small cell lung cancer: A meta-analysis. Oncotarget 2016, 7(49):81292-81304.

11. Mahmood S, Bhatti A, Syed NA, John P: The microRNA regulatory network: a far-reaching approach to the regulate the Wnt signaling pathway in number of diseases. $J$ Recept Signal Transduct Res 2016, 36(3):310-318.

12. Shukla KK, Misra S, Sankanagoudar S, Sharma H, Choudhary GR, Pareek P, Vishnoi JR, Sharma P: Recent scenario of long non-coding RNAs as a diagnostic and prognostic biomarkers of prostate cancer. Urol Oncol 2020.

13. Sullivan MC, Graham PH, Alexander EK, Ruan DT, Nehs MA, Gawande AA, Moore FD, Jr., Howitt BE, Strickland KC, Krane JF et al: Prevalence of Contralateral Tumors in Patients with Follicular Variant of Papillary Thyroid Cancer. J Am Coll Surg 2017, 224(6):1021-1027.

14. Fang L, Cai J, Chen B, Wu S, Li R, Xu X, Yang Y, Guan H, Zhu X, Zhang L et al: Aberrantly expressed miR-582-3p maintains lung cancer stem cell-like traits by activating Wnt/beta-catenin signalling. Nat Commun 2015, 6:8640.

15. Jin $X$, Guan $Y$, Sheng H, Liu Y: Crosstalk in competing endogenous RNA network reveals the complex molecular mechanism underlying lung cancer. Oncotarget 2017, 8(53):91270-91280.

16. Zhou W, Tian D, He J, Wang Y, Zhang L, Cui L, Jia L, Zhang L, Li L, Shu Y et al: Repeated PM2.5 exposure inhibits BEAS-2B cell P53 expression through ROS-Akt-DNMT3B pathway-mediated promoter hypermethylation. Oncotarget 2016, 7(15):20691-20703.

17. Zhao YR, Wang JL, Xu C, Li YM, Sun B, Yang LY: HEG1 indicates poor prognosis and promotes hepatocellular carcinoma invasion, metastasis, and EMT by activating Wnt/beta-catenin signaling. Clin Sci (Lond) 2019, 133(14):1645-1662.

18. Puisieux A, Brabletz T, Caramel J: Oncogenic roles of EMT-inducing transcription factors. Nat Cell Biol 2014, 16(6):488-494.

19. Yang S, Liu Y, Li MY, Ng CSH, Yang SL, Wang S, Zou C, Dong Y, Du J, Long X et al: FOXP3 promotes tumor growth and metastasis by activating Wnt/beta-catenin signaling pathway and EMT in nonsmall cell lung cancer. Mol Cancer 2017, 16(1):124.

20. Pan J, Fang S, Tian H, Zhou C, Zhao X, Tian H, He J, Shen W, Meng X, Jin X et al: IncRNA JPX/miR33a-5p/Twist1 axis regulates tumorigenesis and metastasis of lung cancer by activating Wnt/betacatenin signaling. Mol Cancer 2020, 19(1):9. 
21. Siriwardhana C, Khadka VS, Chen JJ, Deng Y: Development of a miRNA-seq based prognostic signature in lung adenocarcinoma. BMC Cancer 2019, 19(1):34.

22. Huang S, Zou C, Tang Y, Wa Q, Peng X, Chen X, Yang C, Ren D, Huang Y, Liao Z et al: miR-582-3p and miR-582-5p Suppress Prostate Cancer Metastasis to Bone by Repressing TGF-beta Signaling. Mol Ther Nucleic Acids 2019, 16:91-104.

23. Xie $M$, Yu T, Jing $X$, Ma L, Fan $Y$, Yang F, Ma P, Jiang H, Wu X, Shu $Y$ et al: Exosomal circSHKBP1 promotes gastric cancer progression via regulating the miR-582-3p/HUR/VEGF axis and suppressing HSP90 degradation. Mol Cancer 2020, 19(1):112.

\section{Figures}

A

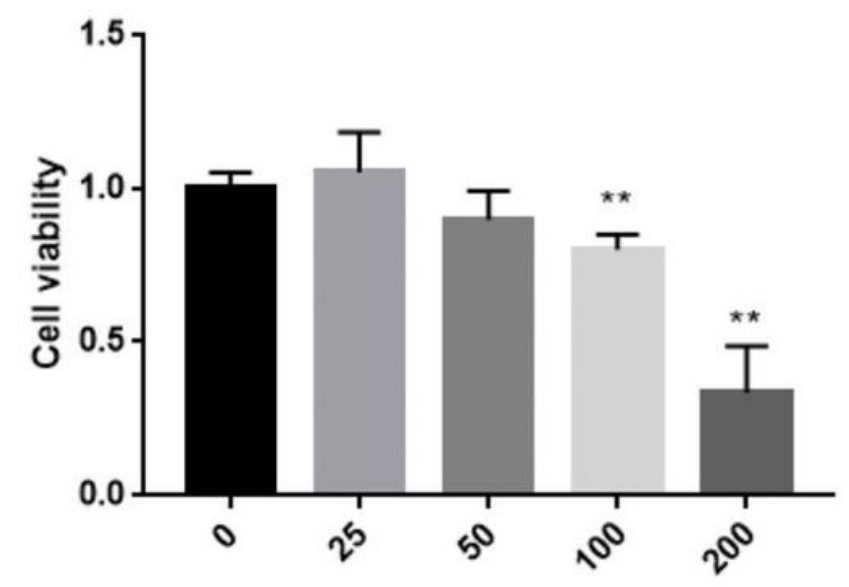

$\mathrm{PM}_{2.5}(\mu \mathrm{g} / \mathrm{mL})$
$\mathrm{B}$

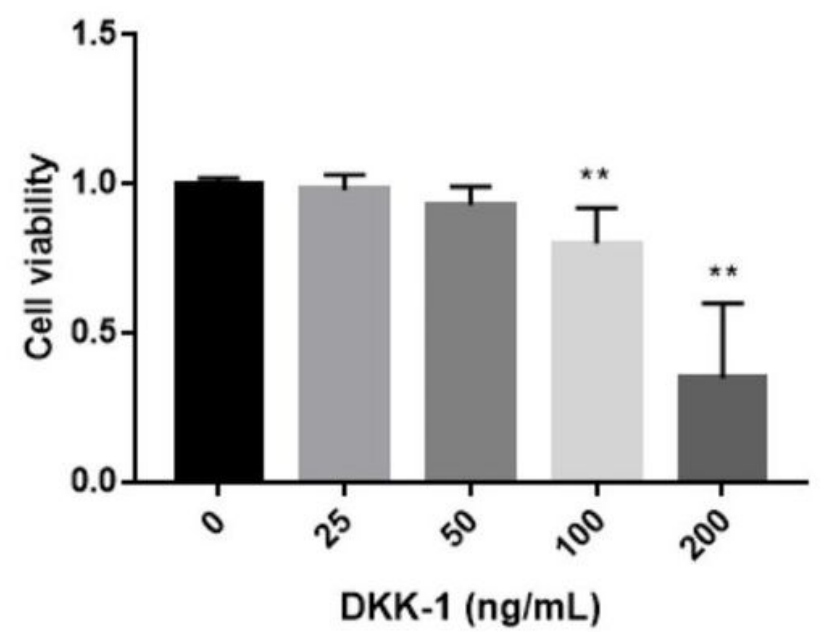

Figure 1

The A549 cytotoxicity of atmospheric PM2.5 and DKK-1. (A) The viability of A549 cells after treated with a concentration gradient of atmospheric PM2.5 $(0,25,50,100,200 \mu \mathrm{g} / \mathrm{mL})$ for 24 hours. (B) The viability of A549 cells after exposed to a concentration gradient of DKK-1 $(0,25,50,100,200 \mathrm{ng} / \mathrm{mL})$ for 24 hours. In comparison with the control group, $* * \mathrm{P}<0.01$. 
A

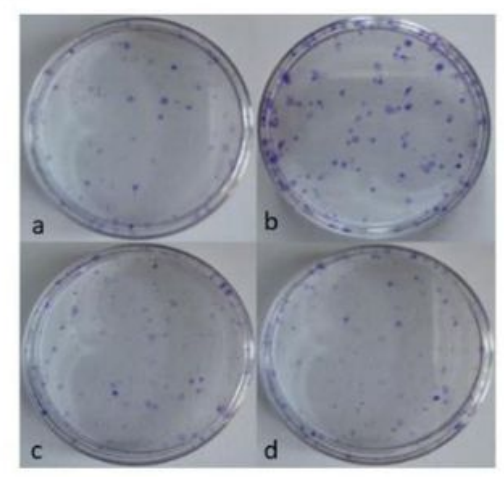

B

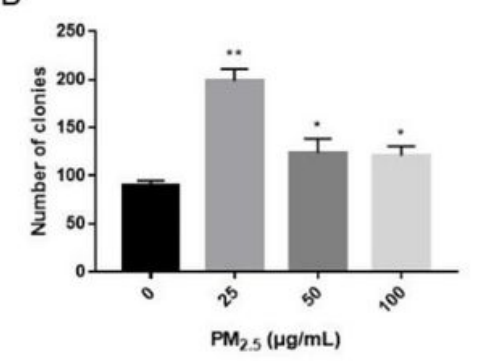

C

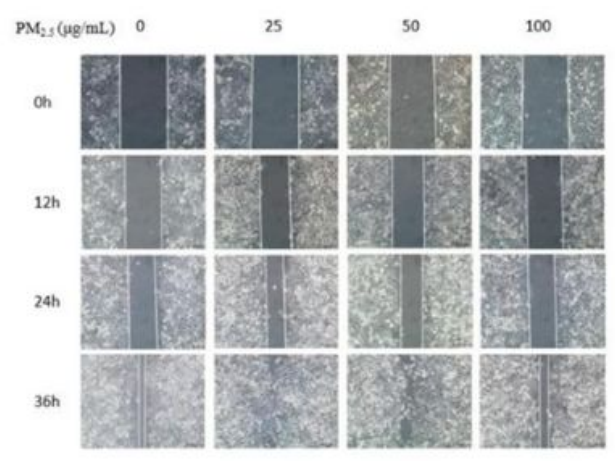

D

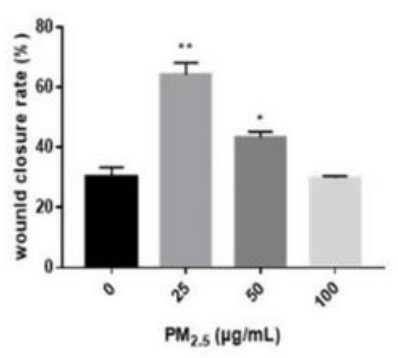

$\mathrm{E}$

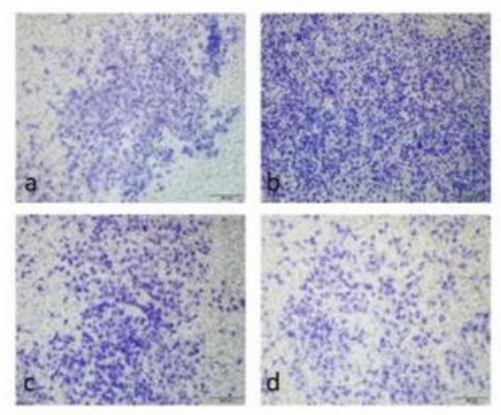

$\mathrm{F}$

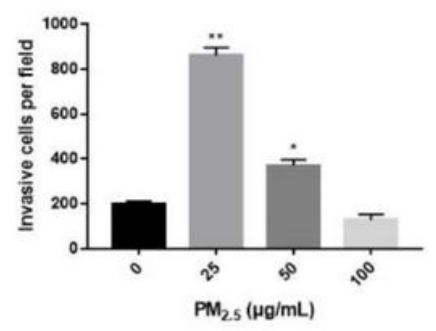

Figure 2

The effects of PM2.5 on the proliferation, migration and invasion of A549 cells. (A) and (B) show the cell cloning situation and column chart of $A 549$ cells after treated with a concentration gradient of atmospheric PM2.5 $(0,25,50,100 \mu \mathrm{g} / \mathrm{mL}$ ) for 24 hours (crystal violet staining). (C) and (D) show the changes of scratch healing degree of A549 cells treated with concentration gradient atmospheric PM2.5 $(0,25,50,100 \mu \mathrm{g} / \mathrm{mL})$ for different times, as well as the histogram of the wound closure rates of the concentration gradient groups after 24 hours of exposure. (E) and (F) show the invasive A549 cells and column chart after treated with atmospheric PM2.5 $(0,25,50,100 \mu \mathrm{g} / \mathrm{mL}$ ) for 24 hours (crystal violet staining, 100 times). In comparison with simple solvent group (0 group), ${ }^{\star} \mathrm{P}<0.05,{ }^{\star *} \mathrm{P}<0.01$. 
A
$\mathrm{PM}_{2.5}(\mu \mathrm{g} / \mathrm{mL})$
0
6.25
12.5
25
$\beta$-Actin

Vimentin

E-cadherin

B
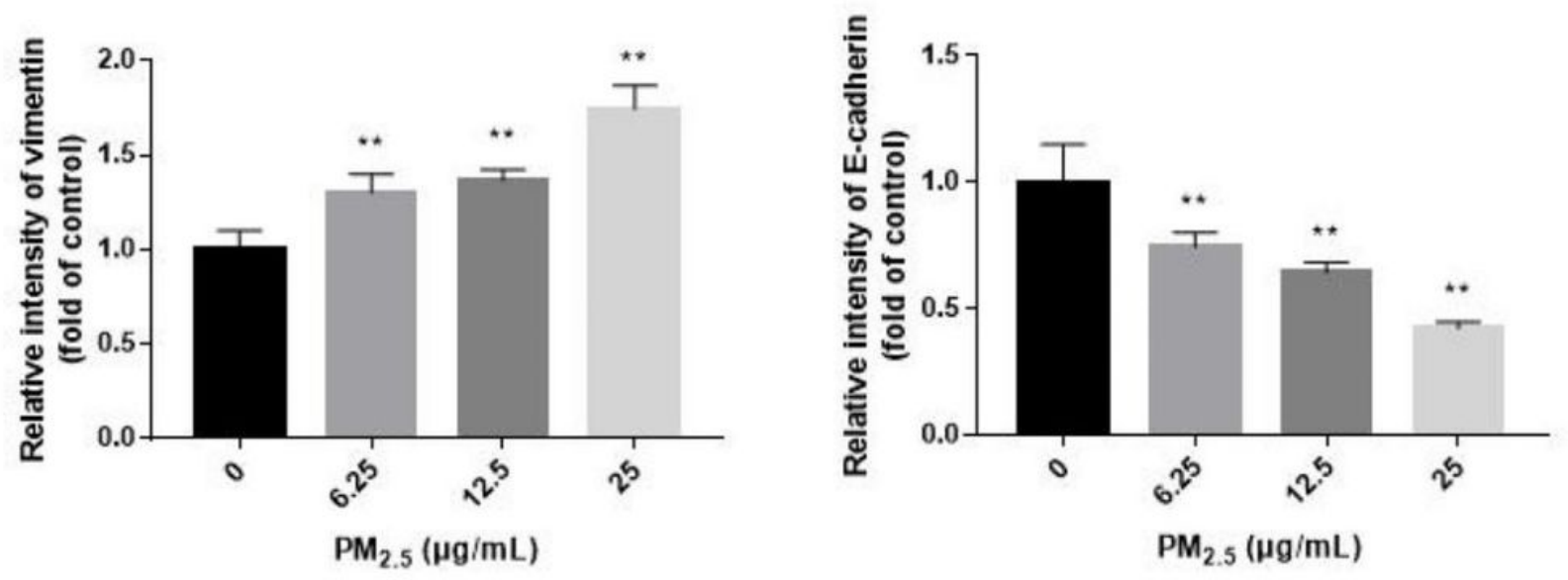

Figure 3

The expression levels of EMT related proteins in A549 cells after exposure to a concentration gradient of atmospheric PM2.5 $(0,6.25,12.5,25 \mu \mathrm{g} / \mathrm{mL})$. In comparison with simple solvent group (0 group), *P $<0.05, * \star \mathrm{P}<0.01$. 
A

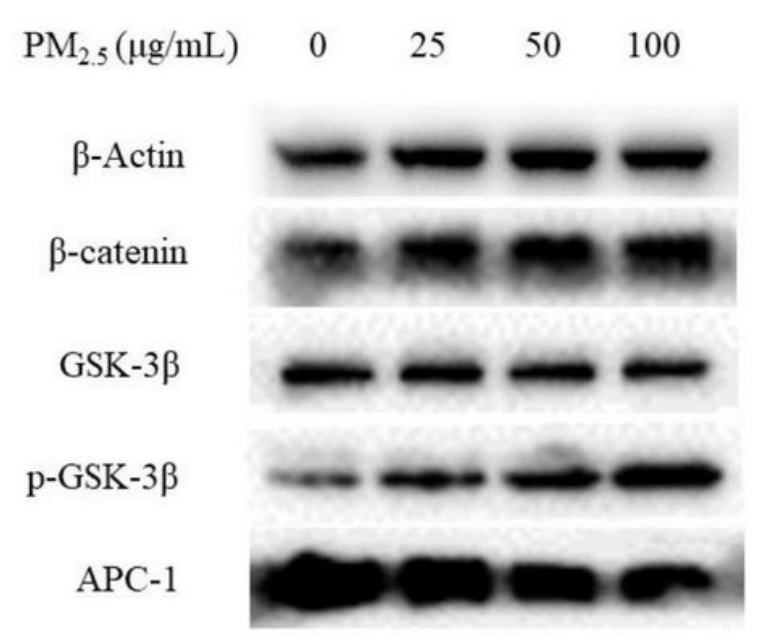

B
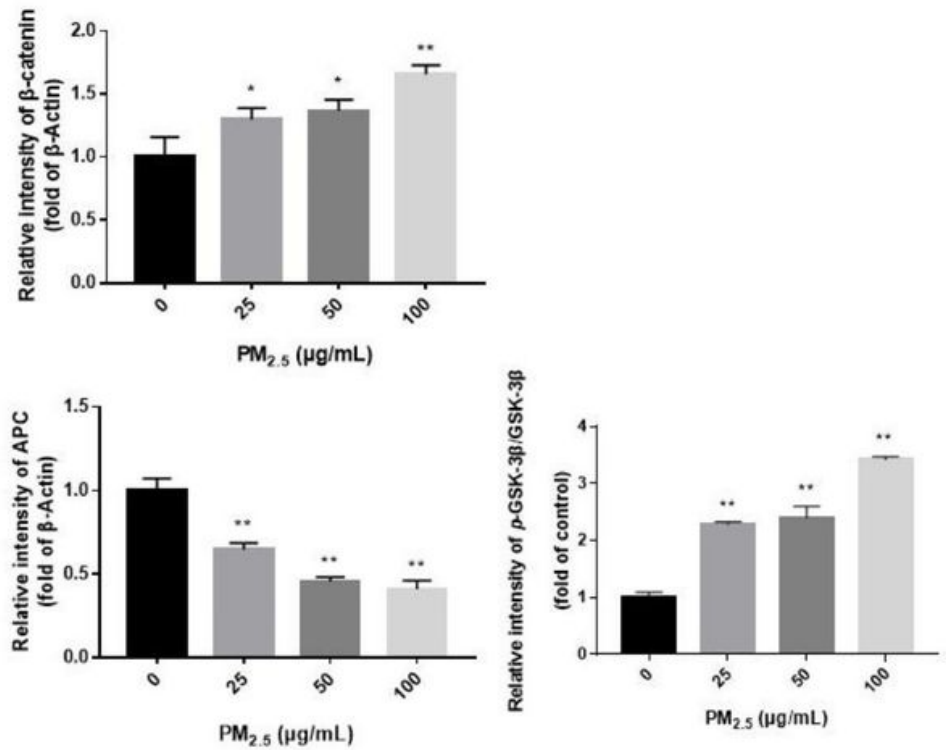

\section{Figure 4}

The relevant-protein levels of Wnt/ $\beta$-catenin pathway in A549 cells after exposure to concentration gradient of atmospheric PM2.5 $(0 \otimes 25 \rrbracket 50 \otimes 100 \mu \mathrm{g} / \mathrm{mL})$. In comparison with simple solvent group, *P $<0.05 \rrbracket \star * \mathrm{P}<0.01$. 


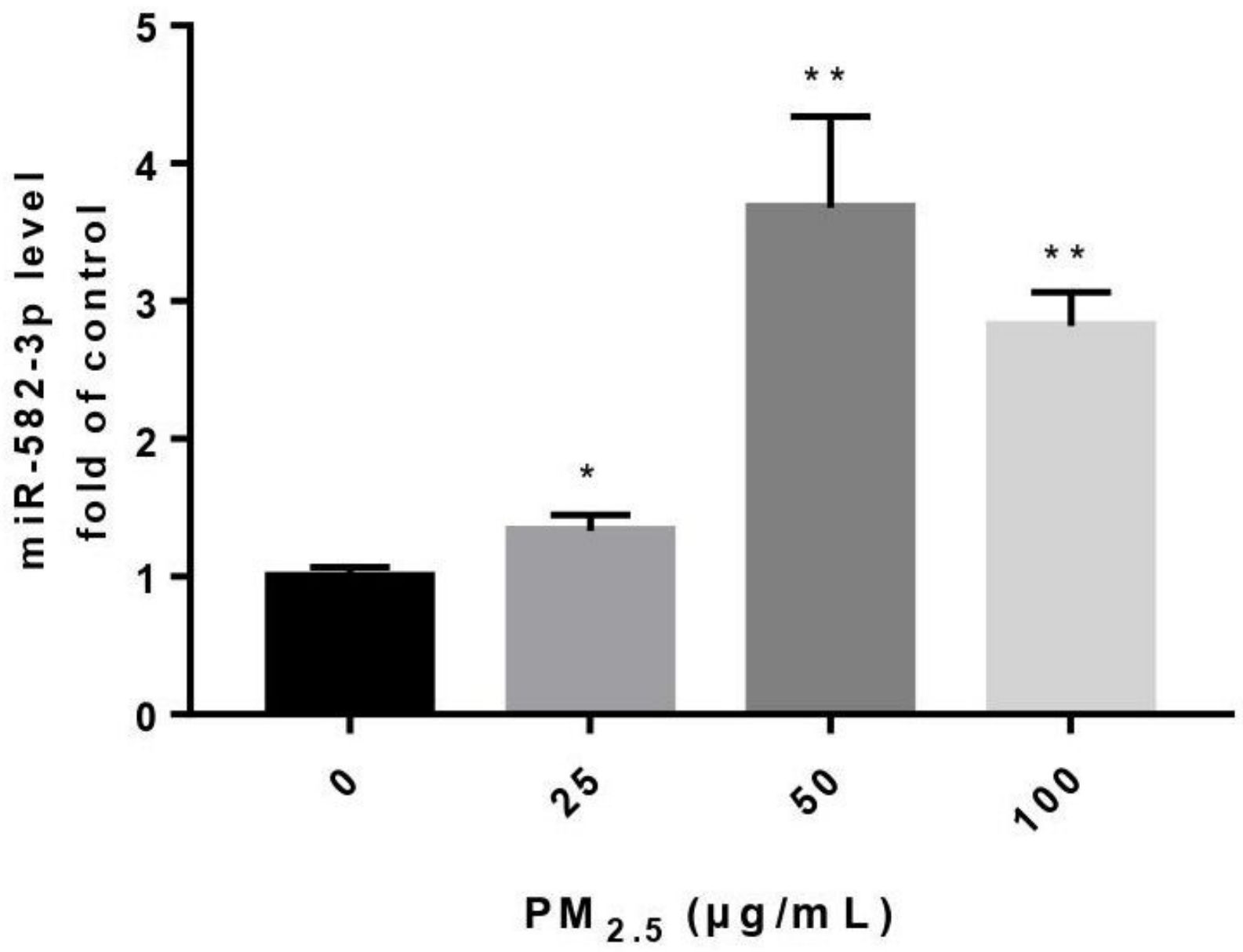

Figure 5

The level of miR-582-3p in A549 cells treated with different concentrations of PM2.5 (0®25ه50冈100 $\mu \mathrm{g} / \mathrm{mL}$ ) was detected by qPCR, using U6 as an internal control. In comparison with simple solvent group, $\star \mathrm{P}<0.05 \rrbracket * * \mathrm{P}<0.01$. 


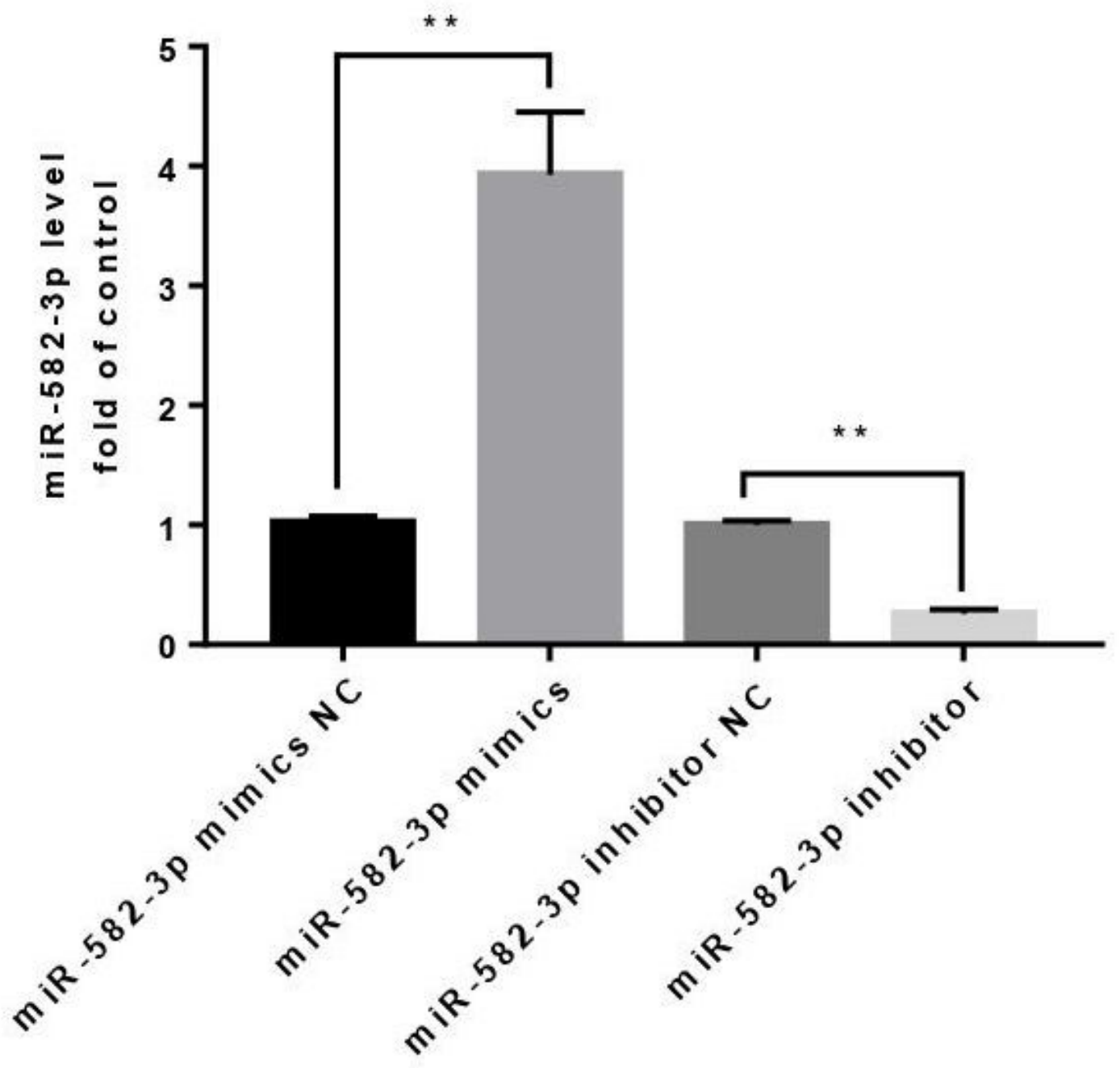

Figure 6

The levels of miR-582-3p in A549 cells that equally transfected with miR-582-3p mimics NC, miR-582-3p mimics, miR-582-3p inhibitor NC or miR-582-3p inhibitor was detected by qPCR method, using U6 as an internal control. In comparison with inter-group, ${ }^{*} \mathrm{P}<0.05 \rrbracket \star \star \mathrm{P}<0.01$. 
A

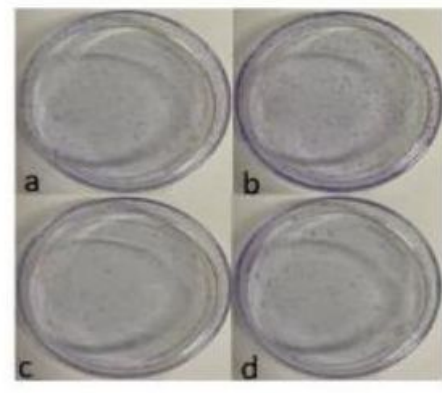

B

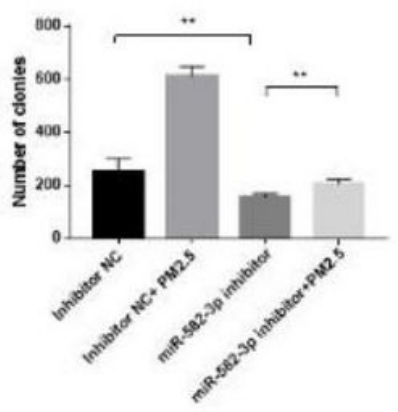

C

Th

$12 \mathrm{~h}$

$24 \mathrm{~h}$

$36 \mathrm{~h}$

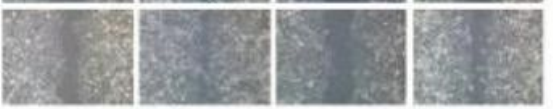

$\mathrm{D}$

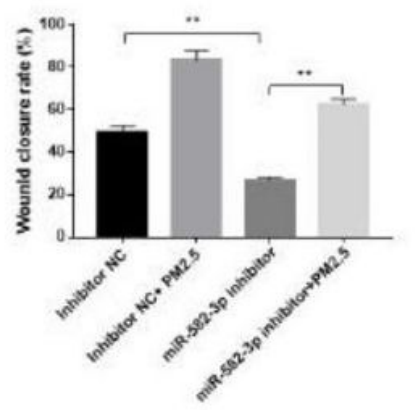

$\mathrm{E}$

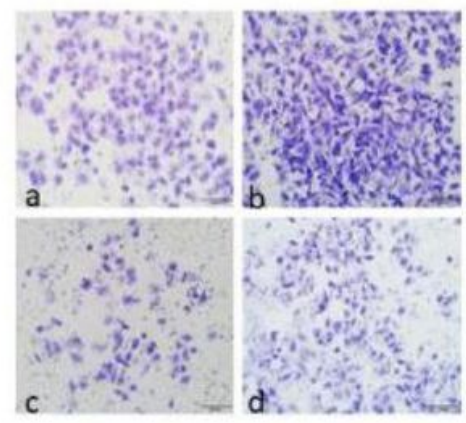

$\mathrm{F}$

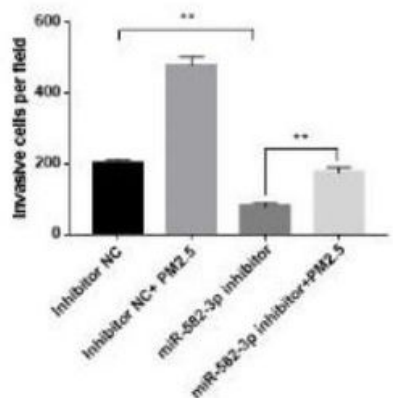

\section{Figure 7}

MiR-582-3p mediated PM2.5-induced proliferation, migration and invasion of A549 cell. (A) are the cell cloning of A549 cells in each group (crystal violet staining); a is Inhibitor NC, b is Inhibitor NC+ PM2.5, c is miR-582-3p inhibitor, $d$ is miR-582-3p inhibitor+PM2.5. (B) is the column chart of the clonal number of cells in groups. (C) are the changes of scratch healing degree of A549 cells in each group and different times. (D) is the column chart of the wound closure rates of A549 cells in each group after 24 hours of exposure. (E) are the invasive cells in each group (crystal violet staining, 100 times). (F) is the column chart of cell invasion number in each group. In comparison with inter-group, ${ }^{*} \mathrm{P}<0.05,{ }^{\star \star} \mathrm{P}<0.01$. 
A

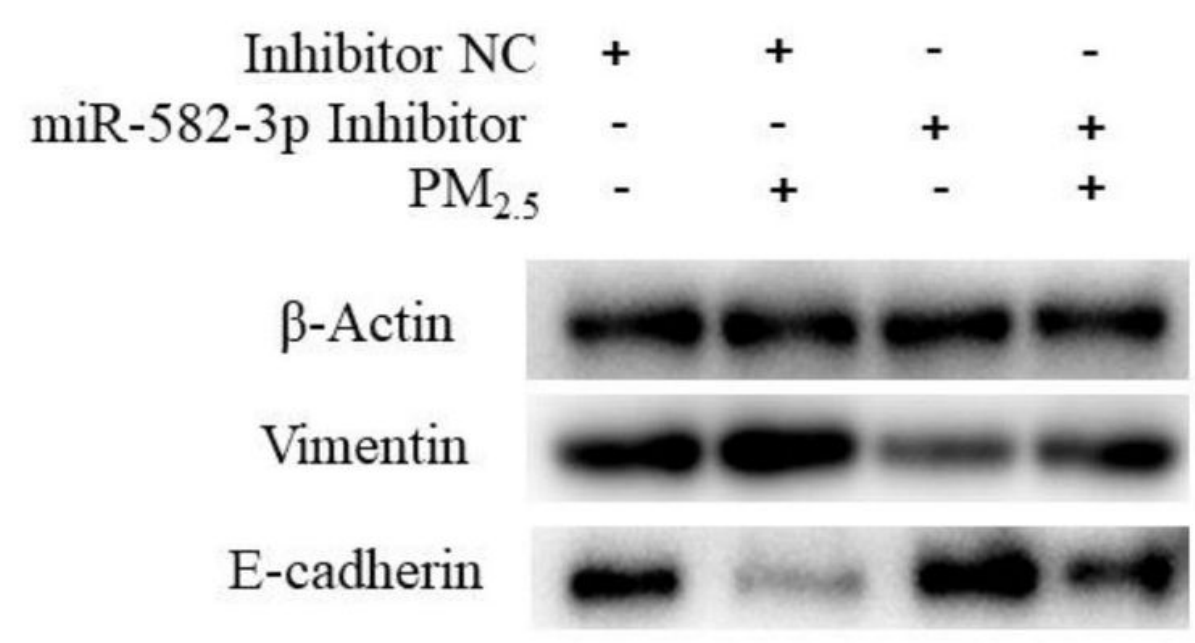

B
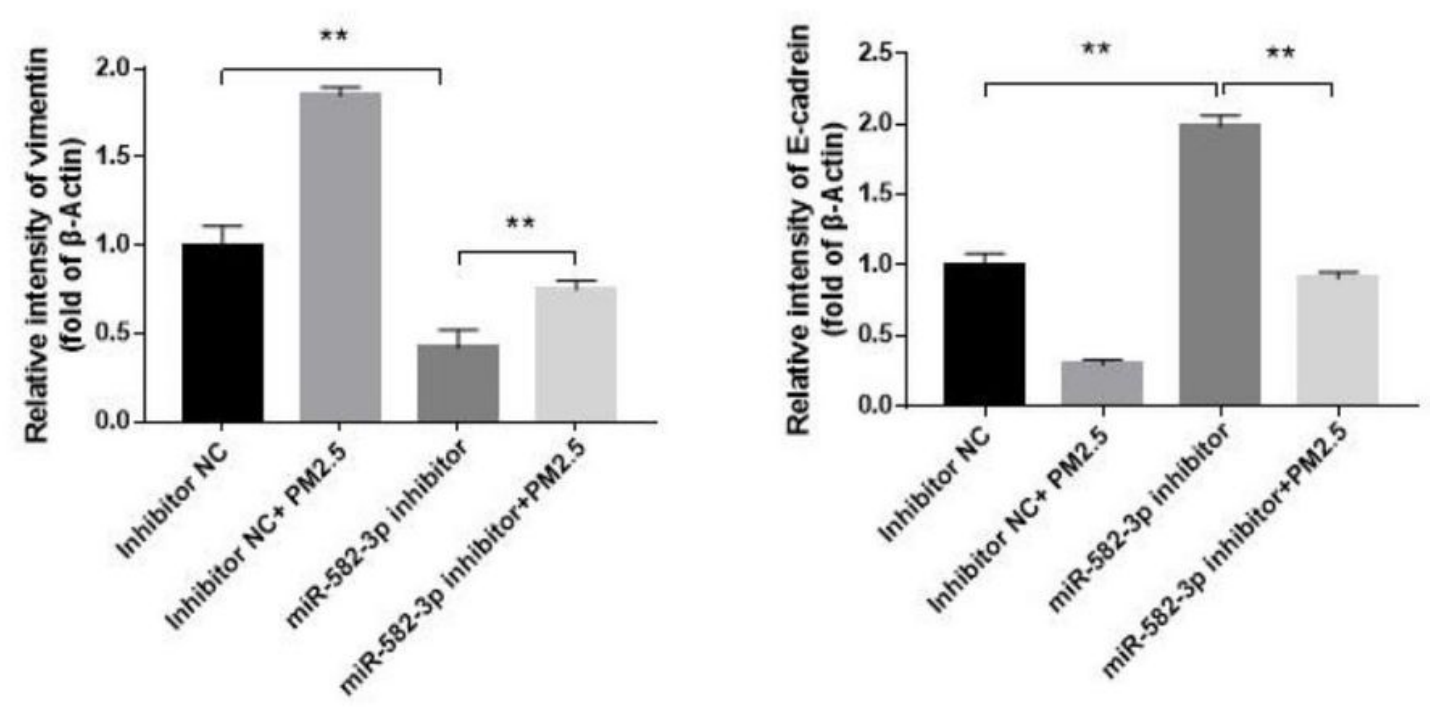

Figure 8

MiR-582-3p mediated the EMT of A549 cells after atmospheric PM2.5 treatment. (A) are the protein bands of Vimentin, E-Cadherin and $\beta$-actin. (B) is the column chart of the relative levels of Vimentin and $\mathrm{E}$ cadherin. In comparison with inter-group, ${ }^{*} \mathrm{P}<0.05, * * \mathrm{P}<0.01$ 
A

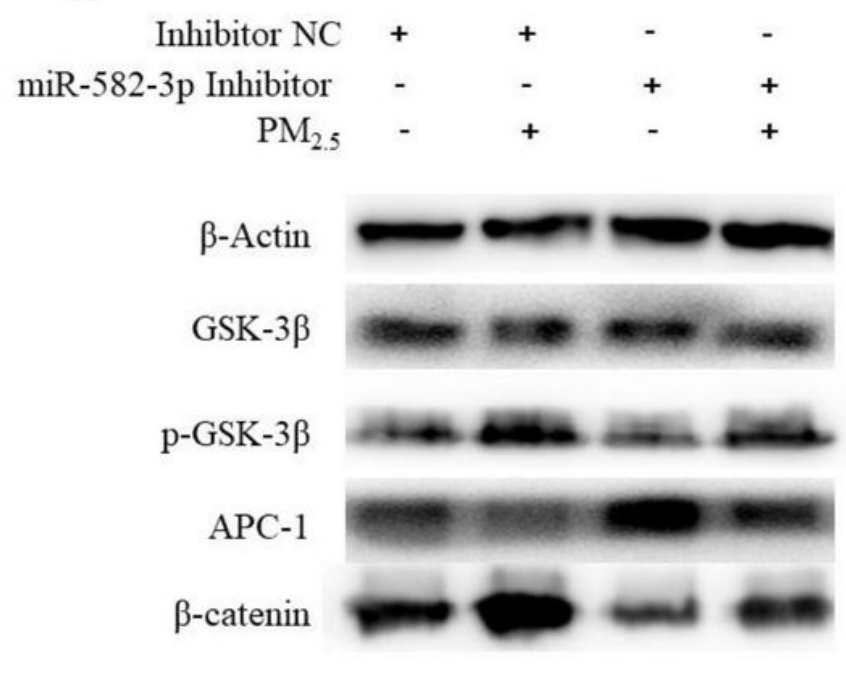

$\mathrm{B}$
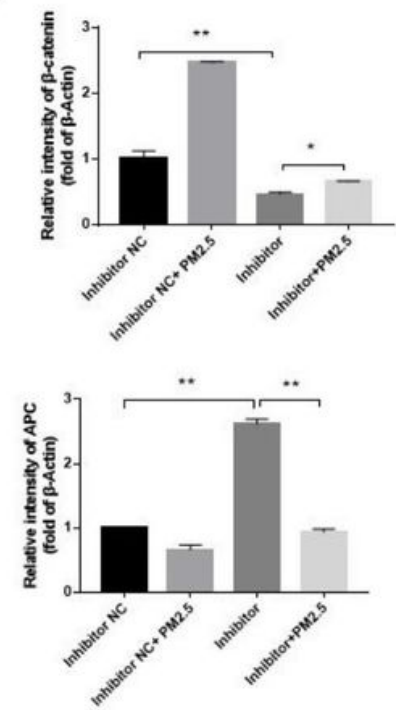

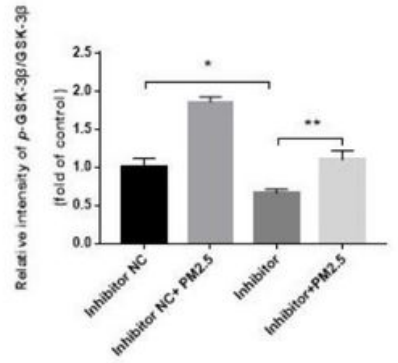

\section{Figure 9}

MiR-582-3p mediated the activation of Wnt/ $\beta$-catenin pathway of A549 cells after atmospheric PM2.5 exposure. (A) are the protein expression bands. (B) is the column chart of the relative levels of $A P C \square \beta-$ catenin and $p-G S K-3 \beta / G S K-3 \beta$. In comparison with inter-group, ${ }^{*} P<0.05,{ }^{*} \mathrm{P}<0.01$. 
A

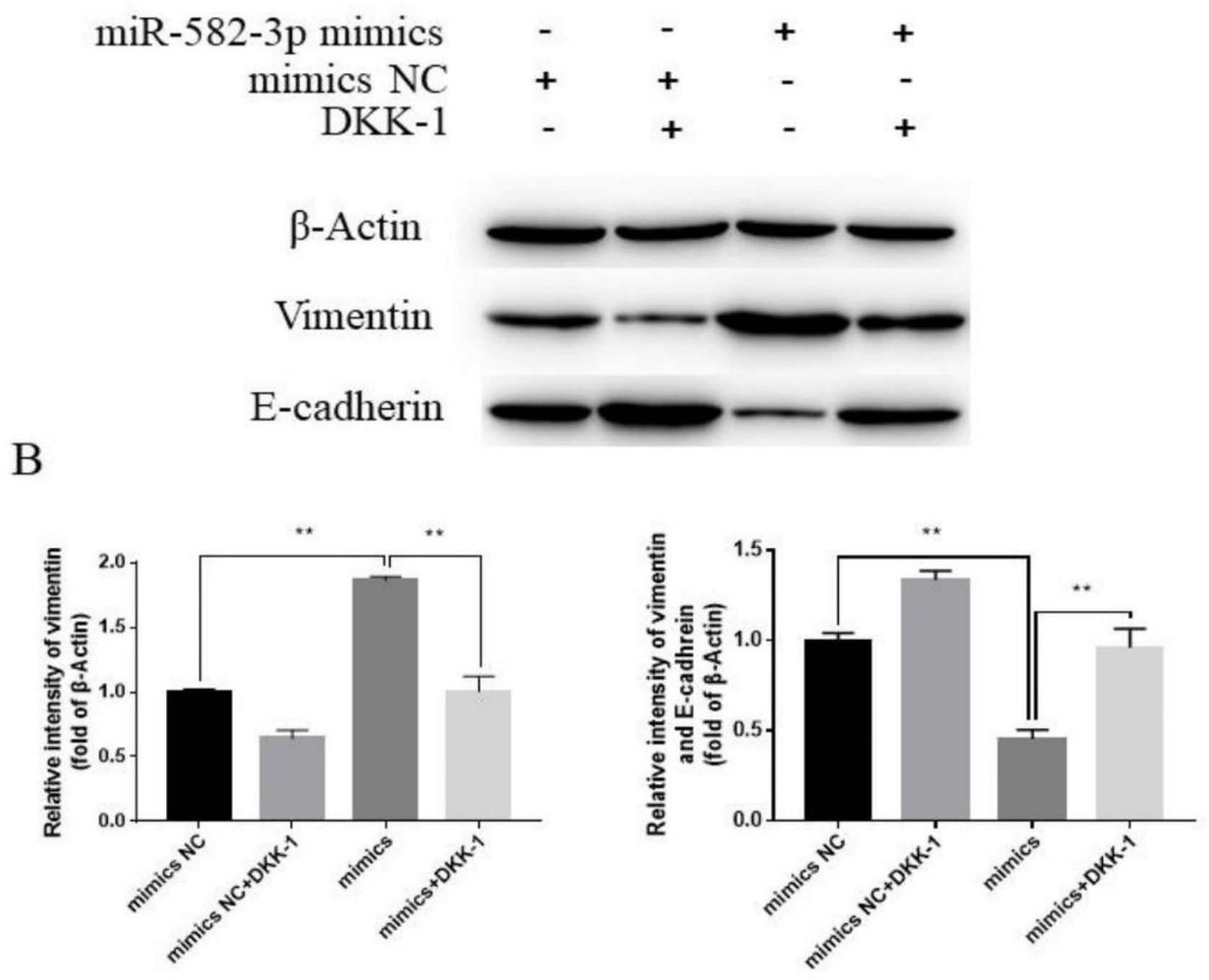

Figure 10

MiR-582-3p regulated the EMT of A549 cells through the Wnt/ $\beta$-catenin signaling pathway. MiR-582-3p mimics NC or miR-582-3p mimics was transfected into A549 cells respectively, and then treated with DKK1 according to the groups (mimics NC, mimics NC + DKK-1, mimics, mimics + DKK-1). The EMT of A549 cells in each group is detected subsequently. $(A)$ are the protein bands of Vimentin, E-Cadherin and $\beta-$ actin. (B) is the column chart of the relative levels of Vimentin and E-cadherin. In comparison with intergroup, $* \mathrm{P}<0.05,{ }^{*} \mathrm{P}<0.01$.

\section{Supplementary Files}

This is a list of supplementary files associated with this preprint. Click to download.

- SupplementaryMaterial.docx 